\title{
石炭液化油の水素化処理反応に与える 触媒硫化条件の影響
}

\author{
侑藤 芳樹*，三未 啓司，白石 稔

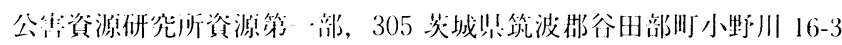

(昭利 62 作 2 月 25 月受理)

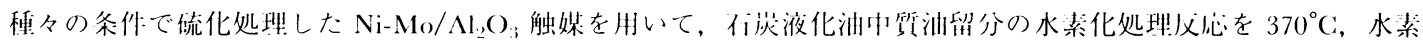

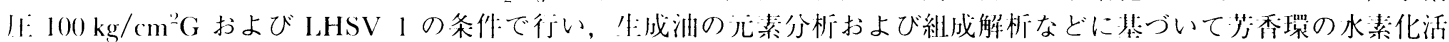

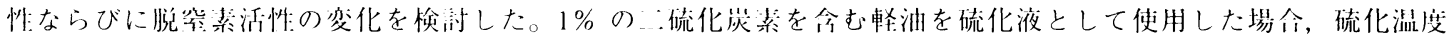

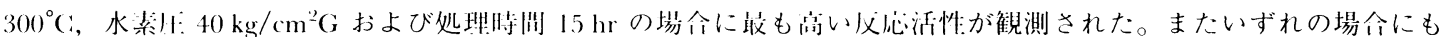

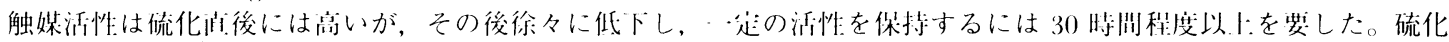

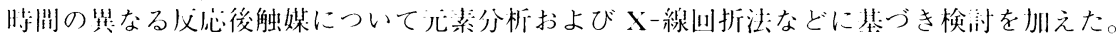

\section{1. 緒言}

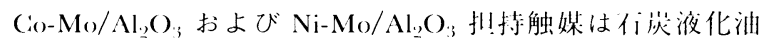

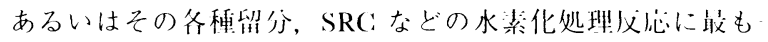
般们に使朋されている触媒の 一つである。11.21著考らはこれま でこれらの触媒を用いた液化油中啠油留分の水絭化処理必忍を

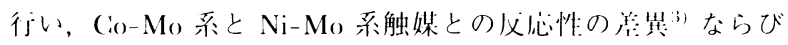
に牛成油の組成変化”などについて考察してきた。これらの触

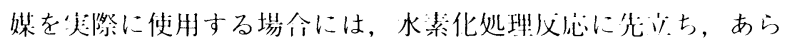

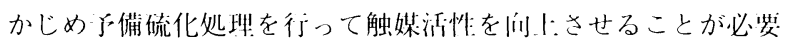
である。流化处理条作は本米, 原料液化油の性状, 水素化処理 条作などによって沈起されるべきものであるが，しかし・般に は们油系重油の脱硫処理の連軽尖験などから䋊験的に設足され ている例が多く，不荻液化油を対象とした場命の硫化条作と螌 媒活性，生成油組成の変化などについては緗に検䞑されてい

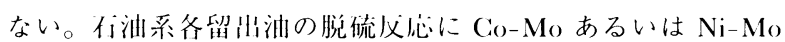

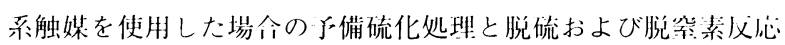

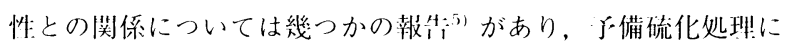
よって触媒活性が们、すること, さらに処理う法の違いによる

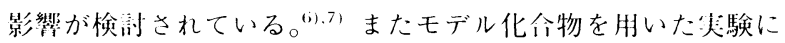
より多䍗芳;香族扩よび芳香族系究素あるいは酸素化介物の水絭 化ならびに脱へテロ必心速度や必伈機構についての検湖がなさ

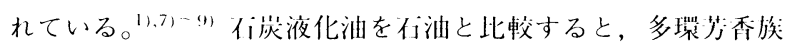
化命物抢よびへテロ化命物の贪存摔が高く”、般にはこれらの 化偒が Mo 系触媒の活性を低下させると推測されることな

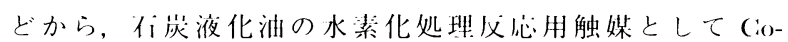
$\mathrm{Mo} / \mathrm{Al}_{2} \mathrm{O}_{3}$ または $\left.\mathrm{Ni}-\mathrm{Mo} / \mathrm{Al}_{2} \mathrm{O}\right)_{3}$ 触媒を使用する場介にはイ油

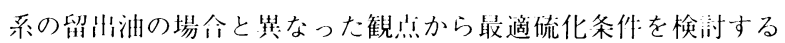

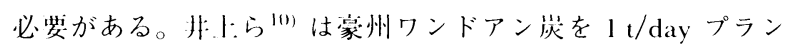
卜を用いて液化して得られた齐種沸点籁用の液化油について,

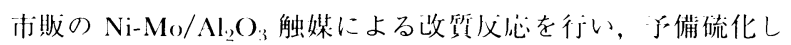

* 逨絡先
なかった場介の牛成油の $\mathrm{f}_{\mathrm{a}}$ が硫化した場介に比べて非常に高 いことから，前者では水素化活性が低下していること，また武 料油中に硫溃が多革令まれていたりまたは硫黄化令物を添加し た場介には いる。また淟田らいは $\gamma$ ーアルミナにMoをはじめとする冬種 全属を抽持し洞製した触媒の水素化抢よび水素化分解活快につ いて，モデル化令物を用いた必忍によって検讨し，さらに XPS 分析などによって触媒の活性状態について解析している。 しかし脱究素あるいは脱酸少义心忍については触れておらず边際 の液化油での伈とは挙動が異なると考えられる。

本研究では種々の条俳で硫化した市敗の $\mathrm{Ni}-\mathrm{Mo} / \mathrm{Al}_{2} \mathrm{O}_{3}$ 触媒

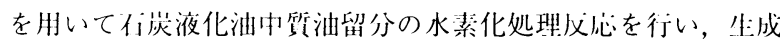
油の元素分析， ${ }^{13}$ C - NMR 解析および組成解析などに基づいて

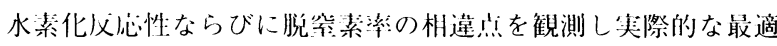
硫化条作を検瀜した。一般にMo 系触桇は硫化モリブデンの 形態で高い水奖化および脱穿素活性を発現するとされている

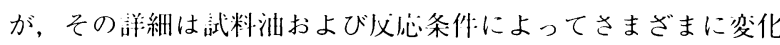
すると考えられる。そこで本研究では史に，使用後触媒につい ての元交分析，X-線回折による解析を試み，高活性触媒の化 兴的㧍よび物理的構造についても訯を試みた。

\section{2. 実験}

使用した液化油は鉄系ダス卜触媒の你在下，家州ワンドアン 菼を $1 \mathrm{t} /$ day 溶剂液化プラントを用いて連続速転尖験を行って

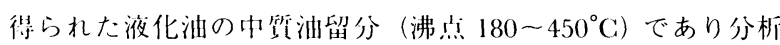

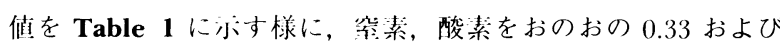
$1.83 \mathrm{wt} \%$ 会んでいる。この中筫留分原料油の組成などについ

Table 1 Analysis of Coal Derived Middle Distillate

\begin{tabular}{ccccccc}
\hline $\begin{array}{c}\text { Sp. Gr } \\
15 / 4^{\circ} \mathrm{C}:\end{array}$ & $\begin{array}{c}\text { Vis. } \\
\left(50^{\circ} \mathrm{C}\right) \\
\mathrm{CSt}\end{array}$ & Carbon & $\begin{array}{r}\text { Hydrogen Nitrogen Oxygen } \\
(\text { wt } \%)\end{array}$ & $\begin{array}{c}\mathrm{H} / \mathrm{C} \\
\text { atomic } \\
\text { ratio }\end{array}$ \\
\hline 0.9962 & 3.17 & 88.82 & 8.78 & 0.33 & 1.83 & 1.178 \\
\hline
\end{tabular}


ては以前報年したのでここでは詳しい說明を省略する。

実験は $\mathrm{Ni}-\mathrm{Mo}_{0} / \mathrm{Al}_{2} \mathrm{O}_{3}$. I業触媒（日本ケッチェン社製 $\mathrm{KF}$ 840）を使用し，触媒无てん量 $20 \mathrm{~m} /$ の管型必伈器を備えた小 型高厂流通式必心装崷によった。触媒の子備硫化処理は，1\% の二硫化岸素を含む軽油を通油して必忍温度 $300 \sim 400^{\circ} \mathrm{C}$, 水 素压: $20 \sim 100 \mathrm{~kg} / \mathrm{cm}^{2} \mathrm{G}$ ，通油時䦗 $0 \sim 20 \mathrm{hr}$ の範讲で変化させ て行った。なお LHSV 抢よび水素: 硫化液比は抢の掞の $1 \mathrm{hr}^{-1}$ 抢よび $1,000 ： 1(\mathrm{vol} / \mathrm{vol})$ と夙足した。触媒硫化後の液化汌

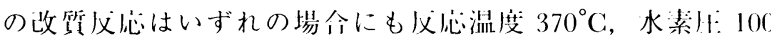
$\mathrm{kg} / \mathrm{cm}^{2} \mathrm{G}$, LHSV $1 \mathrm{hr}^{-1}$ 拈よび水素: 液化油比 $1,000: 1$ ( $\mathrm{vol} / \mathrm{vol})$ の条俳で行い，通油時䦌ごとに牛成油を採邛して分

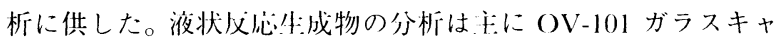
ピラリーカラム（陗径 $0.20 \mathrm{~mm}$ ，产さ $50 \mathrm{~m}$ ）を供えた FID) 検 出器付のガスクロマトグラフにより，荻素，水素の元素分析に はＣH 分析計ならびに究素会存最の分量には化学発光分析泫 および究素検出器を備えたガスクロマトグラフを使用した。成 分の间分のため，OV-17ガラスキャピラリーカラム（唒往 $0.20 \mathrm{~mm}$ ，挂さ $50 \mathrm{~m}$ ) を備えたガスクロマトグラフ抄よび GC-MS を併用した。さらに洋綀な成分組成の间分のため, 部の生成油については $10 \mathrm{wt} \%$ カセイソーダ水浴液抢よび 1.5 wt \% 硫酸水溶液による酸性，掹基性成分ならびに中性の抽们 分離を行い，極性成分の解析を試みた。

\section{3. 結果および考察}

\section{$3 \cdot 1$ 水素化処理反応に及ぼす触媒硫化温度の影響}

水素止 $40 \mathrm{~kg} / \mathrm{cm}^{2} \mathrm{G}$, LHSV $1 \mathrm{hr}^{-1}$ および硫化時闬 $15 \mathrm{hr} の$ 定条作で硫化温度を 300,350 扩よび $400^{\circ} \mathrm{C}$ と变化させて触 媒の硫化処理を行い，その後引き続いておのおの液化油を通油

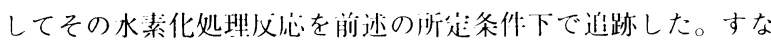
わち生成油中の齐成分の組成，脱究装澅などの性状变化を通油 時㨽ごとに解析し，抢の抢の硫化処理条作の異なる触媒の場令 の綃果を比挍検讨した。 $300^{\circ} \mathrm{C}$ で触媒を硫化处理した豩介を例

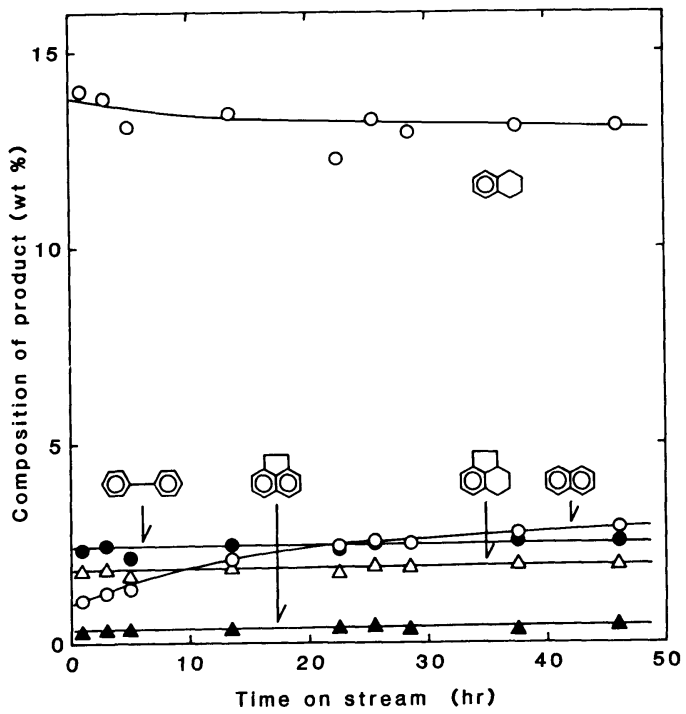

Fig. 1 Composition of Products on the Hydrotreating of Coal Derived Middle I)istillate
にとって水素化处理牛成油組成の経時変化の概要を Fig. 1 打 よびFig. 2 にホした。Fig. 1 によると液化油通油時阙の経過 とともにテトラリン尘成量は徐々に減少し，逆にナフタレンの 牛成量は增玑してくる。后忍よるガス成分の発生がほとんど 想めら机なかったことと考え们わせると，触媒硫化诂後すなわ 七液化油通油初期にはナフタレンからテトラリンへの水素化活

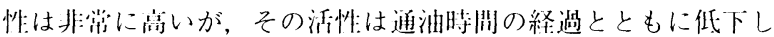
てくることがわかる。通油 $30 \mathrm{hr}$ 経過後には屾少の少:成虽に人 きな変化はなく比較的父足な活性状態に到達したものと考えら れる。钼測されたテトラリン/ナフタレン比約 4.5 は原料油中 の比摔 0.46 よりもはるかに大きく，高い水絭化活性が保持さ れている。しかし Fig. 1 に付就したビフェニル，アセナフテ ン，テトラヒドロアセナフテンの非成量はほとんど変化してい ない。これらの成分の原料油中での贪存維は扰の扰の 2.78 , 2.55 および 0.48 wt％であり，Fig. 1 にホした牛成油巾の令 行摔と比挍するとビフェニルについてはあまり効果的な水素化 成心は起こって抢らず，一片アセナフテンからテトラヒドロア セナフテンへの成心はみやかに進行していることが执かる。

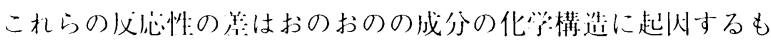
のと若えられる。Fig. 2 には间様にフェナンスレンとその水 少化唀洎休の組成変化をホした。1，2，3，4-テトラヒドロフェ ナンスレンの少成虫はあまり变化しないのに対して，1，2，3， 4, 5, 6, 7, 8-オクタヒドロフェナンスレンの牳成星は通洲初期 には人きいが急速に低下し，逆に9、10-ジヒドロフェナンスレ ンおよびフェナンスレンはやや增玑してくる。4種の唀漯体の

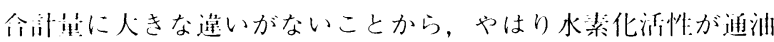

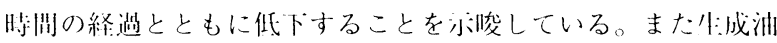
巾にフェノール、クレゾールなどははとんど娭川されなかった のに刘して、ジベンゾフラン湍度は道油时䦌に関係なくほぼ。 迄であり，煌料油の埸苓に比挍してさほど減少していないこと から環状酸䒺の脱路必忍はあまり起こっていないと考えられ

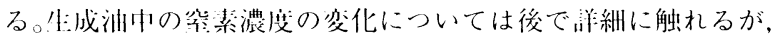

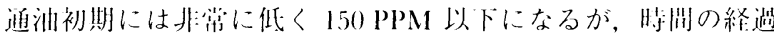

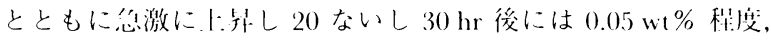

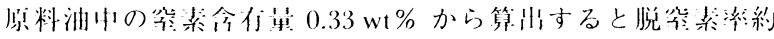
85 wt\% で落ち着く倾们を見せている。

以、少成油糺成などの経時变化の概装によると，硫化処理を 終えた触媒に液化油を通油すると初期には少甭族览化水少の水

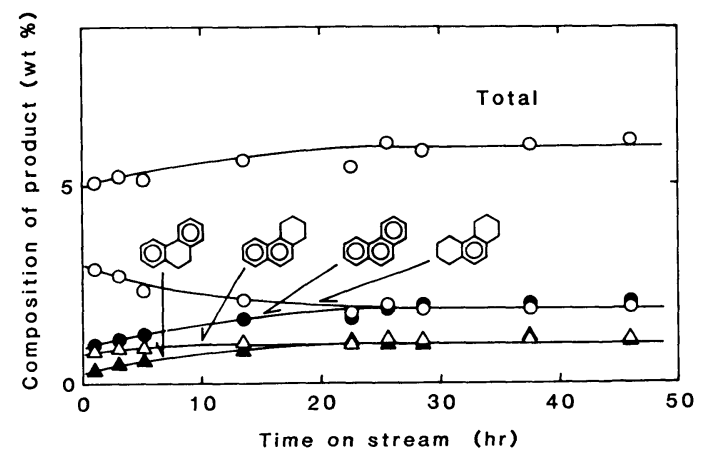

Fig. 2 Composition of Phenanthrene Derivatives on the Hydrotreating of Coal Derived Middle Distillate 


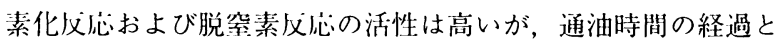
ともに失活してくることがわかった。さらにこれら触媒の活性 変化を実験的に観測するにはナフタレン，フェナンスレンとそ れらの水素化誘導体との生成比ならびに生成油中の究素濃度の 測定が最も敏感であることがわかったので硫化温度，時問およ び硫化時の水素压などの違いによる触媒活性変化の評価にはこ れらの成性を指標として使用し，あわせて生成油の元素分析 值，值などと比較した。

Fig. 3 に予備硫化温度を 300,350 および $400^{\circ} \mathrm{C}$ と变化させ て触媒を調製したあと挔の拉の液化油中質油留分の水素化処理 を行った場今の生成油中の究素濃度変化を示した。いずれの場 今も通油初期での究素濃度は非常に低く 110 160 PPMの範 用であり脱究素率としては 95 97 wt％を示している。しかし 通油時䦌の経過とともに生成油中の空素濃度は上昇し触媒の脱 帘素活性が低下してくる。ただし通油時間 $30 \mathrm{hr}$ 以降では究素 濃度に大きな变化は見られず，触媒活性が努尘してきたことを 示している。予備硫化温度の筫なる触媒を用いて得られた究素

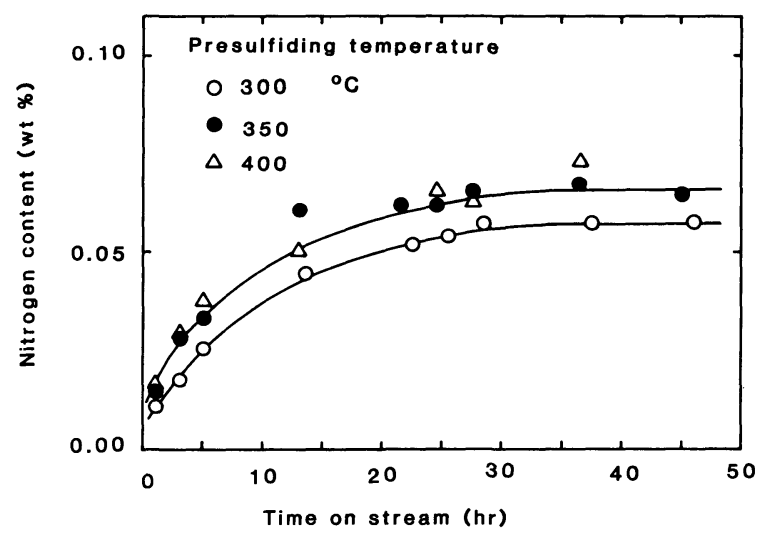

Fig. 3 Effect of Presulfiding Temperature on Denitrogenation
濃度の变化によると硫化温度 $300^{\circ} \mathrm{C}$ の場合が 350 および $400^{\circ} \mathrm{C}$ の場合よりも通油初期から $50 \mathrm{hr}$ までの範䎴では究素濃 度が若十低く, $\mathrm{Ni}-\mathrm{Mo} / \mathrm{Al}_{2} \mathrm{O}_{3}$ 触媒の予備硫化温度としては $300^{\circ} \mathrm{C}$ が適当であると考えられる。しかし通油時間 $30 \mathrm{hr}$ 以降 の究素濃度をもとに脱窑素率を算出すると予備硫化温度の違い による差恭は 81〜83 wt％の範用にあり，処理温度による触媒 活性の相違は本実駼温度範网ではあまり火きくないと推測され る。生成油中のテトラリン/ナフタレン， 1, 2, 3, 4, 5, 6, 7, 8オクタヒドロフェナンスレン/フェナンスレンおよびジヒドロ ピレン/ピレン生成比を Table 2 に，また生成油の元素分析值 および ${ }^{13} \mathrm{C}-\mathrm{NMR}$ 解析による $\mathrm{f}_{\mathrm{a}}$ 值を Table 3 に示した。

Table 2 中のテトラリン/ナフタレン生成比によると触媒硫化 温度 300,350 および $400^{\circ} \mathrm{C}$ のいずれの場合にも通油初期には 生成比の值は大きく, 時閌の経過とともに低下し, 通油時閣 $28 \mathrm{hr}$ 以降では大きな変化はなく，また触媒処理条件の違いに よる差はほとんど見られない。オクタヒドロフェナンスレン/ フェナンスレン生成比の場令にもさほど変化は顕著ではないが 通油時閏が経過するに従って生成比が低下し，テトラリン/ナ フタレンの場令と類似の傾们が見られた。しかしジヒドロピレ ン/ピレン生成比は通油初期から $45 \mathrm{hr}$ までほとんど変化して いない。Table 3 に示した生成油の元素分析值，H/C および O/C 原子比ならびに $\mathrm{f}_{\mathrm{a}}$ 值によると,いずれの温度で処理した 触媒の場令にも，H/C 原子比は通油初期には変化するが，そ の後はほとんど変わらない。これに対して $\mathrm{O} / \mathrm{C}$ 原子比および $\mathrm{f}_{\mathrm{a}}$ 值は通油時䦗の経過とともにゆるやかな増加傾们を示してい る。以上のことから水素化活性に及ほす触媒の予備硫化温度の

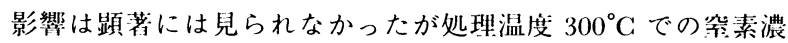
度が最も低かったこと，さらに究素濃度の測芫值の信賴性が酸 素などに比較してかなり高いことから，後述する硫化時䦌およ び予備硫化時の水素压の影響を検㣥する尖験は, 硫化温度 $300^{\circ} \mathrm{C}$ で行った。

Table 2 Effect of Presulfiding Condition on the Ratio of Components in the Products

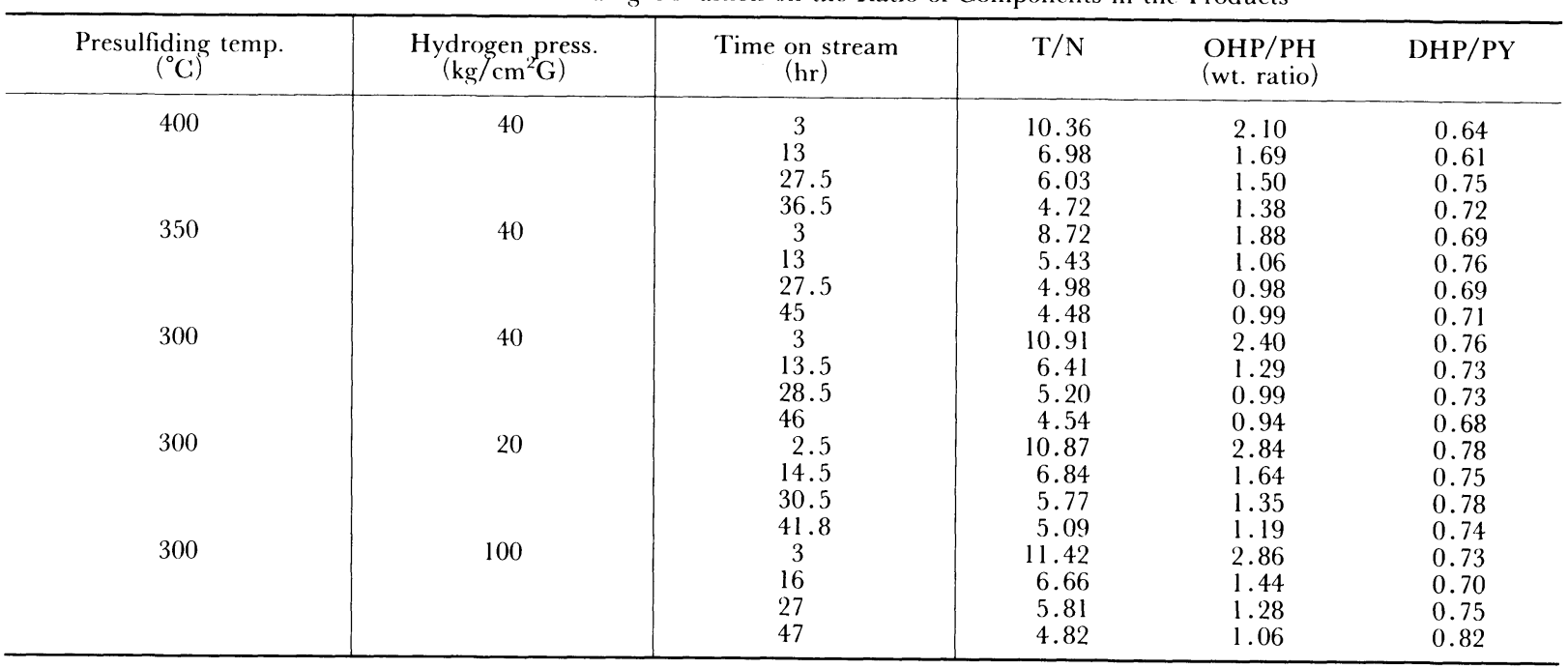

T : Tetralin, $\mathrm{N}:$ Naphthalene

OHP : 1,2,3,4,5,6,7,8-Octahydrophenanthrene

PH : Phenanthrene, DHP : Dihydropyrene, PY : Pyrene 
Table 3 Effect of Presulfiding Condition on the Property of the Products

\begin{tabular}{|c|c|c|c|c|c|c|c|c|c|c|}
\hline \multirow{2}{*}{$\frac{\begin{array}{c}\text { Temp. } \\
\left({ }^{\circ} \mathrm{C}\right)\end{array}}{400}$} & \multirow{2}{*}{$\begin{array}{c}\begin{array}{c}\text { Presulfiding } \\
\text { Time } \\
\text { (hr })\end{array} \\
15\end{array}$} & \multirow{2}{*}{$\frac{\begin{array}{c}\mathrm{H}_{2} \text { Press. } \\
\left(\mathrm{kg} / \mathrm{cm}^{2} \mathrm{G}\right)\end{array}}{40}$} & \multirow{2}{*}{$\begin{array}{c}\begin{array}{c}\text { Hydrotreating } \\
\text { Time on Stream } \\
(\mathrm{hr})\end{array} \\
3\end{array}$} & C & $\begin{array}{c}\text { Ultima } \\
\mathrm{H}\end{array}$ & $\begin{array}{l}\text { analysis } \\
\mathrm{N}\end{array}$ & $\mathrm{O}$ & \multicolumn{2}{|c|}{$\begin{array}{lc}\mathrm{H} / \mathrm{C} & \mathrm{O} / \mathrm{C} \\
\text { Atomic } & \text { Ratio }\end{array}$} & $\mathrm{f}_{\mathrm{a}}$ \\
\hline & & & & 88.64 & 10.73 & 0.029 & 0.57 & 1.44 & 0.0048 & 0.394 \\
\hline & & & 13 & 88.45 & 10.39 & 0.051 & 0.85 & 1.40 & 0.0072 & 0.453 \\
\hline & & & 27.5 & 88.57 & 10.25 & 0.062 & 0.74 & 1.38 & 0.0063 & 0.439 \\
\hline & & & 36.5 & 88.68 & 10.10 & 0.074 & 1.12 & 1.37 & 0.0095 & 0.454 \\
\hline 350 & 15 & 40 & 3 & 88.11 & 10.45 & 0.028 & 0.63 & 1.41 & 0.0054 & 0.411 \\
\hline & & & 13 & 88.29 & 10.34 & 0.061 & 0.58 & 1.40 & 0.0049 & 0.418 \\
\hline & & & 27.5 & 88.57 & 10.01 & 0.066 & 0.81 & 1.35 & 0.0069 & 0.432 \\
\hline & & & 45 & 88.48 & 10.15 & 0.064 & 0.95 & 1.37 & 0.0081 & 0.456 \\
\hline 300 & 15 & 40 & 3 & 88.35 & 10.55 & 0.018 & 0.61 & 1.42 & 0.0052 & 0.396 \\
\hline & & & 13.5 & 88.85 & 10.24 & 0.045 & 0.82 & 1.37 & 0.0069 & 0.440 \\
\hline & & & 28.5 & 89.00 & 10.21 & 0.058 & 0.83 & 1.37 & 0.0070 & 0.459 \\
\hline & & & 46 & 88.68 & 10.04 & 0.057 & 1.14 & 1.35 & 0.0097 & 0.471 \\
\hline 300 & 5 & 40 & 2.75 & 88.32 & 9.86 & 0.046 & 1.16 & 1.33 & 0.0099 & 0.477 \\
\hline & & & 15.5 & 88.73 & 9.74 & 0.085 & 1.48 & 1.31 & 0.0125 & 0.511 \\
\hline & & & 30.0 & 88.88 & 9.71 & 0.091 & 1.50 & 1.30 & 0.0127 & 0.522 \\
\hline & & & 44.0 & 89.10 & 9.78 & 0.087 & 1.24 & 1.31 & 0.0110 & 0.522 \\
\hline 300 & 20 & 40 & 3.0 & 88.55 & 10.29 & 0.023 & 0.95 & 1.38 & 0.0081 & 0.427 \\
\hline & & & 17.5 & 88.70 & 10.11 & 0.055 & 1.24 & 1.36 & 0.0105 & 0.457 \\
\hline & & & 32.5 & 88.89 & 9.93 & 0.064 & 1.13 & 1.33 & 0.0095 & 0.478 \\
\hline & & & 46.5 & 88.85 & 9.94 & 0.072 & 1.01 & 1.33 & 0.0085 & 0.489 \\
\hline
\end{tabular}

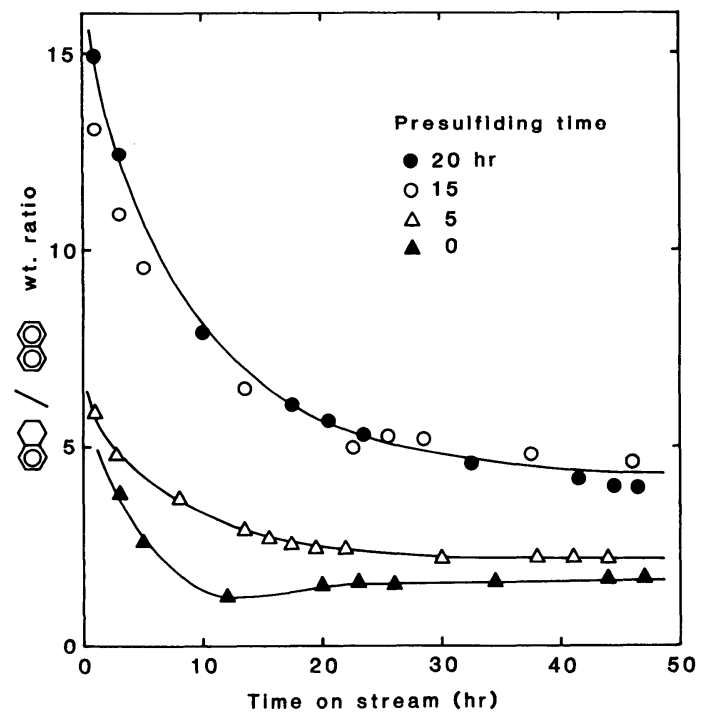

Fig. 4 Effect of Presulfiding Time on the Composition of Products

\section{$3 \cdot 2$ 予備硫化時間および水素圧の影響}

Fig. 4 に予備硫化時洴を $0,5,15$ および $20 \mathrm{hr}$ と変化させた 場介の通油時䦌に対するテトラリン/ナフタレン比の変化を亦 した。テトラリン/ナフタレン比は硫化時阙 0 では, 通油初期 でも非常に低く, $30 \mathrm{hr}$ 以降 1.5 付近の低い值を示した。硫化 時閆 $5 \mathrm{hr}$ の場令にはテトラリン/ナフタレン比は茯た上昇する が通油時䦌 $30 \mathrm{hr}$ 以降でも生成比は 2.0 とやはり低い做であっ た。テトラリン/ナフタレン比は硫化時䦌が $15,20 \mathrm{hr}$ と产くな るにつれて高くなり，いずれの場令にも通油初期には 15 程度 と高く，すぐに低下するものの，硫化時䦌 15 および $20 \mathrm{hr}$ で はおのおの約 6 および 5 であり $40 \mathrm{hr}$ 通油後でも 4 前後と高 かった。硫化時润 $20 \mathrm{hr}$ での䋨果は $15 \mathrm{hr}$ の場令とほとんど変 わって㧍らず，従って硫化処理时洅としては約 $15 \mathrm{hr}$ 以上が必 要かつ十分と考えられる。オクタヒドロフェナンスレン/フェ

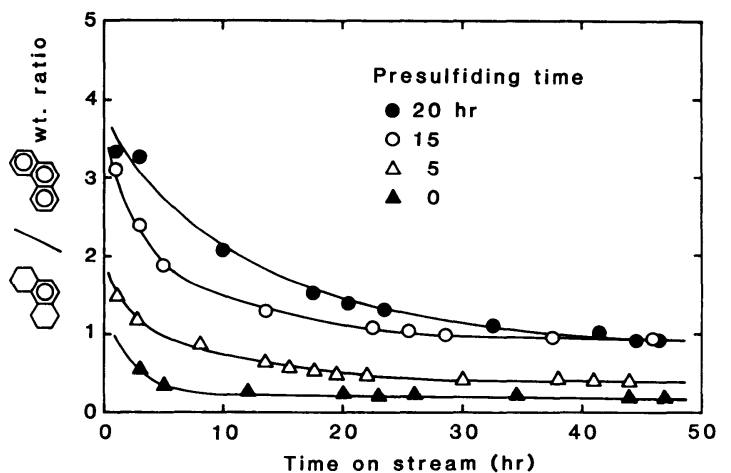

Fig. 5 Effect of Presulfiding Time on the Composition of Products

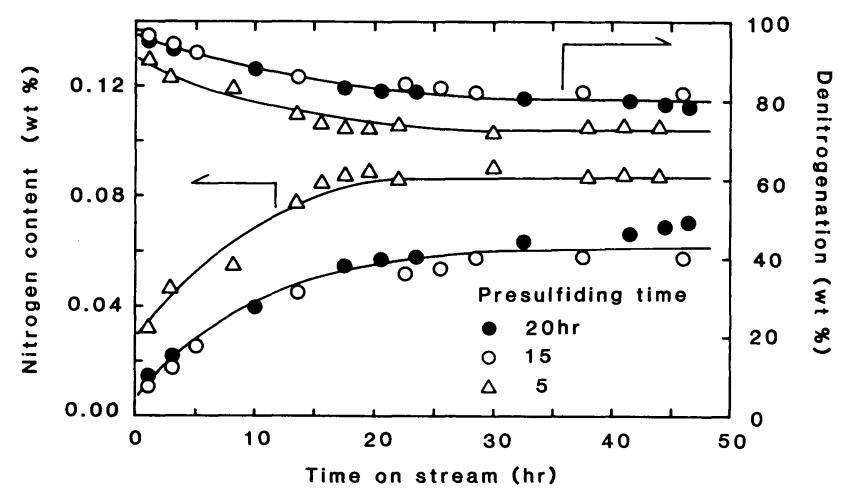

Fig. 6 Effect of Presulfiding Time on Denitrogenation

ナンスレン比についても Fig. 5 に示すように间様の傾问が見 られ，硫化時䦌０の場今には紬成比は萝しく低く，通油時䦌 $10 \mathrm{hr}$ 以降でも約 0.2 であった。硫化時䦌 $5 \mathrm{hr}$ ではこの組成比 は若斗们上するが $30 \mathrm{hr}$ 通油後でも約 0.4 と低い。硫化時㓦 15 および $20 \mathrm{hr}$ の場今には Fig. 5 に亦すように生成比は高く $30 \mathrm{hr}$ 通油の後でも組成比は約 0.8 と一段と高い値を示した。 
硫化時閆 15 および $20 \mathrm{hr}$ の算による組成比の変化はほとんと 見られなかった。またテトラリン/ナフタレン比（Fig. 4)で の絬果と比較すると, 環只数の小さなナフタレン系のおが変化

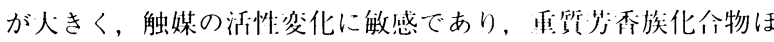
ど触媒の処理方法には鈍感になると推測される。Fig. 6 に触

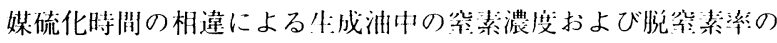
变化をホくした。触媒の硫化後原料油の通油を開始すると，通油 時阔の経過とともに水素化活性が低下してくるのと间様に脱穿 素摔も低下してくる。硫化时间 $15 \mathrm{hr}$ の埸介, 通油後 $1 \mathrm{hr}$ で

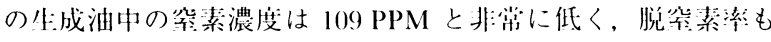
$96.8 \mathrm{wt} \%$ と高い。しかしその後窎素䀼度は $10 \mathrm{hr}$ で約 450 PPM, さらに $20 \mathrm{hr}$ では $520 \mathrm{PPM}$ と增加し, 通油初期に触媒 の脱究素活性が急速に低下してくる。通油後 $30 \mathrm{hr}$ 以上を経過 すると生成油中の究素濃度に大きな変化は見られなくなり触媒 活性が㒸定してきたと考えることができる。Fig. 6 にホした ように硫化時间 $20 \mathrm{hr}$ での結果は $15 \mathrm{hr}$ の場命とほとんど変わ らなかった。しかし硫化時润が $5 \mathrm{hr}$ と知い場介には, 牛成油 中の穿素濃度は通油初期ですでに 323 PPM と简く，脱究素活

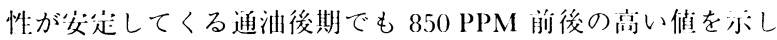
た。従って硫化時䦌が短い場介令には㧍もにモリブデンを硫化す るなど触媒を十分活性化するにはまだ硫黄が不起していると考 えられるが，硫化中に触媒阐を通過した後のガスの組成を経时 的に分析すると硫化時䦌 $5 \mathrm{hr}$ ではすでに硫化水絭の牛成が楒

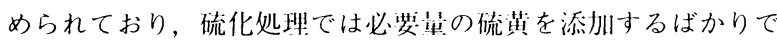
なく, 硫黄份在:下で触媒の活州:状態を形成する熟成期阔が必要 と推測される。以上ナフタレン，フェナンスレンとその水素化

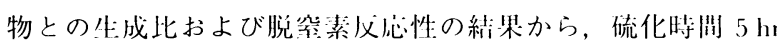
は短すぎ, $15 \mathrm{hr}$ 程度以上の時泟をかけて触媒の硫化を行うこ とが爱当と考えられる。Table 3 にボした条条作下での牛成

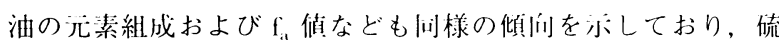
化処理 $5 \mathrm{hr}$ の触媒を使用した坋今の少成油は硫化处理の长い ものと比較して H/C 值が低く，O/C 做, 紫素会们量扰よび : 值が高く，水素化，脱究素抢よび脱酸素必伈とも活性が低く なることが理解できる。

備硫化時の水素历:の影響については，これまでの考察をも とに，予備硫化温度 $300^{\circ} \mathrm{C}$, 硫化時洲 $15 \mathrm{hr}$ の条俳で水素目: 20, 40 㧍よび $100 \mathrm{~kg} / \mathrm{cm}^{2} \mathrm{G}$ とおの扔の変化させて硫化した触 媒を用い，それぞれ听分の条作で液化油の水素化処理仪忍を

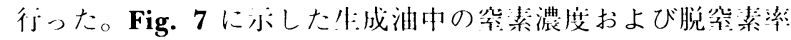
を比挍すると, 硫化時の水尛非が 20 抢よび $100 \mathrm{~kg} / \mathrm{cm}^{2} \mathrm{G}$ の 場仝の脱究素挙動は非常に類似しており, 究素濃度については いずれも水素! $40 \mathrm{~kg} / \mathrm{cm}^{2} \mathrm{G}$ の場介の紏果よりも䯩く，当然脱

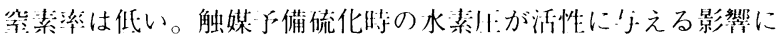

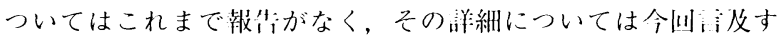
ることはできないが，適切な水素あるいは二硫化岸素分非必 要と考えられる。これに対して硫化時の水细の相違による生 成油中の齐成分の組成にはあまり顕菑な変化は見られなかっ た。Table 2 に付衦したテトラリン/ナフタレン拉よびオクタ ヒドロフェナンスレン/フェナンスレン比によると水綮1: 20 $\mathrm{kg} / \mathrm{cm}^{2} \mathrm{G}$ で硫化処理した触媒でのテトラリン/ナフタレン比が 茯け低く，逆にオク夕ヒドロフェナンスレン/フェナンスレン

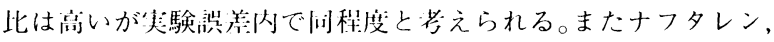
テトラリン， cis 抄よび trans-デカリンを命めたナフタレン関逨 化令物执よび间様にフェナンスレンおよびその水素化唀学体の 総令計量にも大きな差苟はなく，したがって硫化時の水素目のの 違いによる水絭化分解仪忍の活性変化はあまりないと推測され る。

\section{$3 \cdot 3$ 硫化処理と触媒活性}

一般に抽持 Mo 系触媒は MoS . に近い形態で高い活性をを発 現すると推測されており ${ }^{12 y}$, 予供硫化处理は高い活性状態の MoS、を形成するに必贵かつ十分な硫黄を供給する過程と考え ることができる。本实験で使用した，硫化特䦌 0 および $15 \mathrm{hr}$ の場介の成忍後触媒について元素分析を行ったところ Table 4 にホすように硫化時阔０の場介の触媒は $15 \mathrm{hr}$ 処理したもの

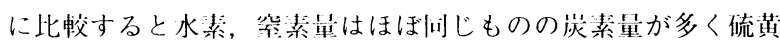
合们星は $1 / 2$ 以下であった。硫化時阙 0 の場介には原料液化 油中に含まれている $0.03 \%$ の硫黄が約 50 時䦌の通油中に触 媒に收り迄まれたものと考えられる。0捛よび 15 時䦌硫化処

Table 4 Analyses of Used Catalysts

\begin{tabular}{|c|c|c|}
\hline $\begin{array}{l}\text { Presulfiding } \\
\text { time (hr) }\end{array}$ & 0 & 15 \\
\hline $\begin{array}{ll}\mathrm{C} & (\mathrm{wt} \%) \\
\mathrm{H} & \\
\mathrm{N} & \\
\mathrm{S} & \end{array}$ & $\begin{array}{l}9.54 \\
1.75 \\
0.59 \\
2.05\end{array}$ & $\begin{array}{l}7.57 \\
1.69 \\
0.59 \\
5.69\end{array}$ \\
\hline
\end{tabular}

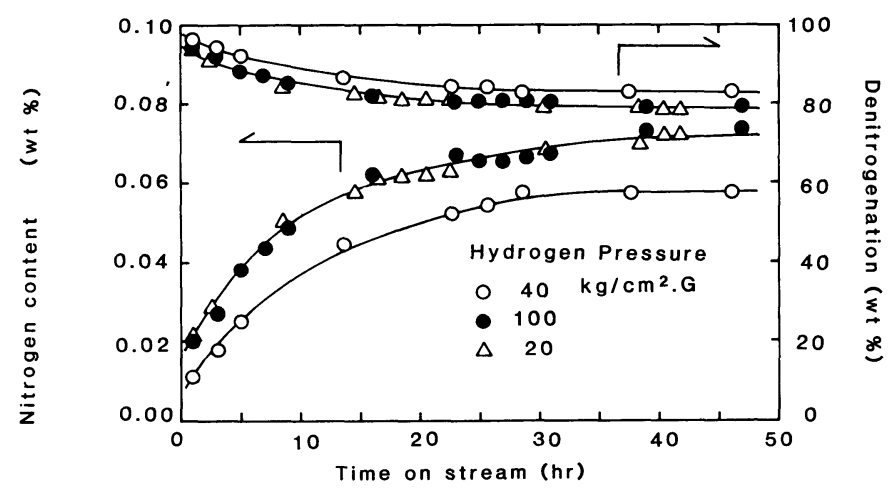

Fig. 7 Effect of Hydrogen Pressure for Presulfiding on Denitrogenation 


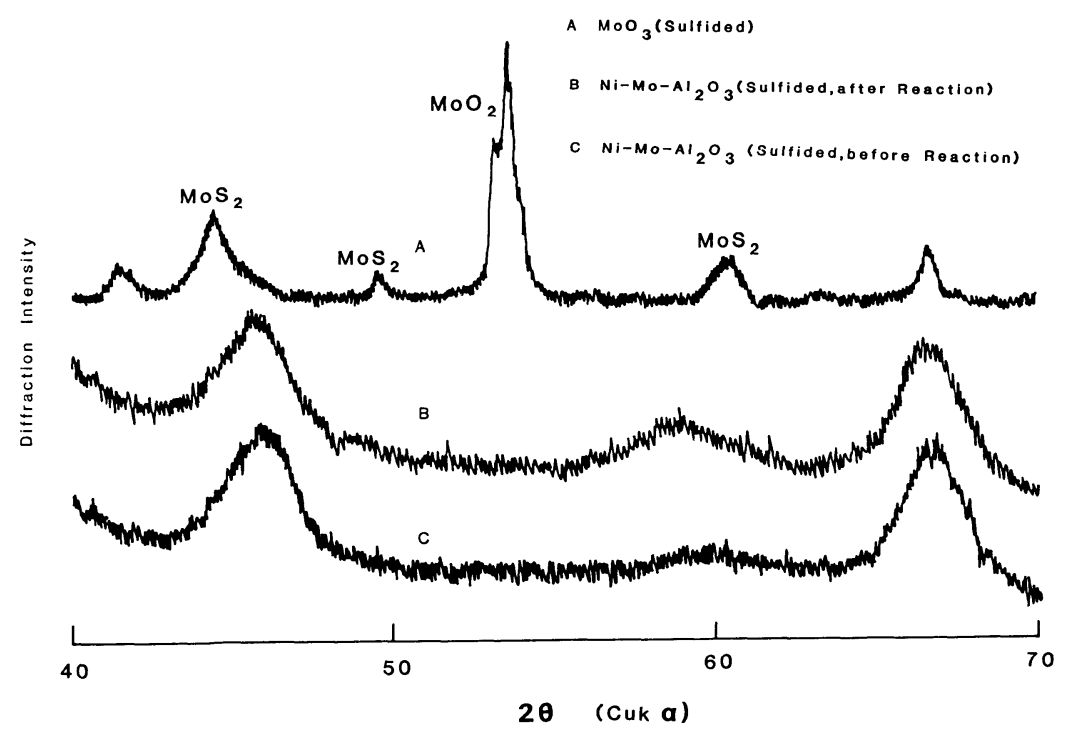

Fig. 8 X-ray Diffraction Pattern for the Catalyst

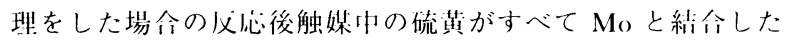

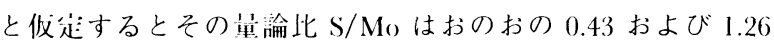
であった。XPS 分析などでの紏果では活性種はMOS.に近い

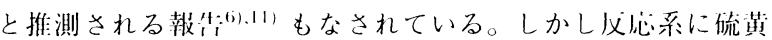

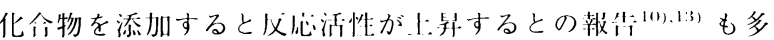
く，従って活性種が MoS ，に近い形態であるにしても多少不

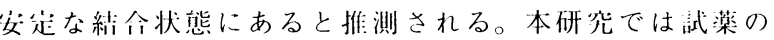
$\mathrm{MoO}_{3}$ を $\mathrm{H}_{2} \mathrm{~S} / \mathrm{H}_{2}$ 你在:下で硫化した梤介の各種硫化モリブデ ン（A）を基準物啠として，15hr 硫化後必心に使用した触媒 （B）抢よび硫化しただけの触婎（C）などの X一線回折を武み た。Fig. 8 の試料 A 中の备ピークについてはJPDS カードな

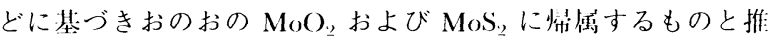
測した。三者の回折絬果を比較すると B，C中の四折栣 $67^{\circ}$ 付

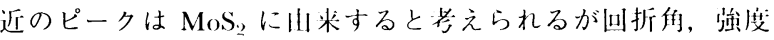
とも処理方法によってほとんど变化せず，Moの伯阙䰙はあま り変化していないと考えられる。これに対して $46^{\circ}$ および $60^{\circ}$ 付近のものは处理方法によって蚛度に等があることから文心活 性と関連した触媒構造の変化とも推測される。今後 $\mathrm{Mo}, \mathrm{S}$ 打 よび $\mathrm{Ni}$ などの分散状態を詳しく閣べるとともに必学動との 関係を啲跡していく必要があると考えられる。

\section{4. 結言}

本研究では市敗の仿油系脱硫触媒として住く知られている

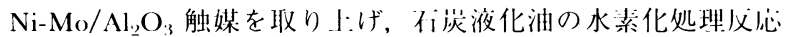
用触媒として使用した場介の最適㱜備硫化条作を検㳔した。触

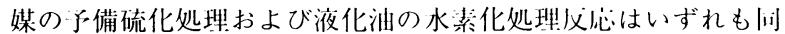

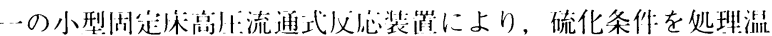

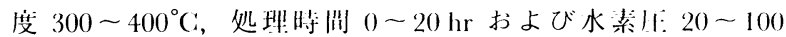
$\mathrm{kg} / \mathrm{cm}^{2} \mathrm{G}$ の範䎴で変化させ，その後引き繶いて液化油の水絭

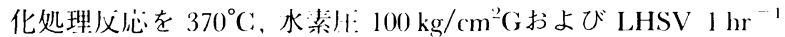
の条作で行い，通油時䦌ごとの牛成油の元少分析ならびに紬成 解析結果の相違を観測して触媒の硫化処理条作の影郘を詊価し た。その絬果触媒の硫化処理に最も钽感でかつ測分精度の高い
生成油の性状闪子は化学発光法による学素分析であり，いずれ の触媒を使用した場介にも脱等素㳯は液化油の通油初期には高

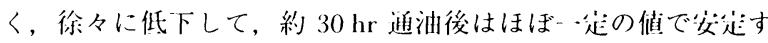
る倾们をホさした。齐通油時湍ごとに採取した生成油中のテトラ リン/ナフタレンおよびオクタヒドロフェナンスレン/フェナン スレン比ならびに生成油の $\mathrm{f}_{: 1}$ 湖などによる水素化仪伈活性の 挙動もほほ问㥞の倾问をホした。種々の条俳で処理された触媒

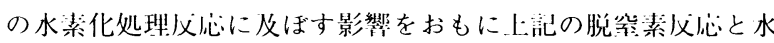
絭化必伈举動によって検村したところ，触媒硫化処理を $1 \%$ の $\mathrm{CS}$ ，を会む軽油を通油して行った場介には，処理温度 $300^{\circ} \mathrm{C}$, 水素师約 $40 \mathrm{~kg} / \mathrm{cm}^{2} \mathrm{G}$ 扩よび処理時润 $15 \mathrm{hr}$ 以上が最 邀と考えられた。硫化处理を行わなかった場令および十分に処

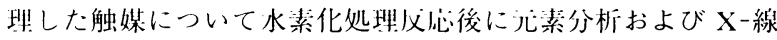
屾折を武みたところ触媒中の Moは $\mathrm{MoS}_{2}$ よりもやや硫㣴の 不足した状態で高い活性をボすことが推測された。

終わりに，本尖験で使用した行踇液化油中筫油留分は $\mathrm{NEDO}$ ・住友金属1:業 (株) 波崎センターより提供されたもの であり，また $\mathrm{Ni}-\mathrm{Mo}_{\mathrm{O}} / \mathrm{Al}_{2} \mathrm{O}_{3}$ 触媒は住友金属鉱川(株)より提供

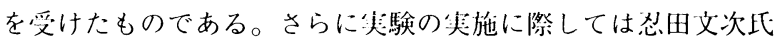
ならびに佐藤勝出氏より多大な御協力をいたたいた。礼して深 く感謝の意を表します。

\section{References}

1) Shah, Y. T., Ed., "Reaction Engineering in Direct Coal Liquefaction" p. 298 (1981), Addison-Wesly Publishing Co.

2) Nakamura, E., Ukegawa, K., Sekiyu Gakkaishi, 29, (3), 187 (1986).

3) Ukegawa, K., Kondo, T., Matsumura, A., Koguchi, K., Nakamura, E., Sekiyu Gakkaishi, 27, (3), 242 (1984).

4) Sato, Y., Ukegawa, K., Kondo, 'T., Matsumura, A., Koguchi, K., Nakamura, E., Sekiyu Gakkaishi, 27, (5), 433 (1984).

5) Laine, J., Pratt, K. C., Trimm, D. L., Ind. Eng. Chem., 
Prod. Res. Dev., 18, (4), 329 (1979).

6) Hallie, H., Oil \& Gias J., 80, (51), 69 (1982).

7) Furimsky, E., Catal. Rev., 25, (3), 421 (1983).

8) Iaine, R. M., Calal. Rev., 25, (3), 459 (1983).

9) Shah, Y. T., Stiegel, G. J., Krishnamurthy, S., Conference on Chemistry and Physics of Coal Utilization, Morgantown, p. 256 (1980).

10) Inoue, Y., Kawamoto, K., Mitarai, Y., Kurachi, K., Hayakawa, K., 20th Coal Science Conference of Japan,
Prep., p. 117 (1983).

11) Shimada, H., Sato, T., Yoshimura, Y., Nishijima, A., Kasuya, S., Abe, M., Ogino, K., 51 th Autumn Meeting of Chemical Society of Japan, Prep., p. 724 (1985).

12) de Beer, V. H. J., van der Aalist, M. J. M., Machiels, C. J., Schuit, G. C. A., J. Catalysis, 43, 78 (1976).

13) Schuit, G. C. A., Gates, B. C., AIChE J., 19, (3), 417 (1973)

\title{
Summary
}

\section{Effect of Presulfiding Condition of Catalyst on the Hydrotreating of Coal Derived Middle Distillate}

\author{
Yoshiki SATo, Keiji Mıkı, and Minoru ShIRaIshi \\ National Research Institute for Pollution and Resources, \\ 16-3 Onogawa, Yatabe-cho, T'sukuba-gun, Ibaraki 305
}

The effect of presulfiding condition for $\mathrm{Ni}-\mathrm{Mo} / \mathrm{Al}_{2} \mathrm{O}_{3}$ catalyst on the hydrotreating of coal derived middle distillate has been evaluated on the basis of elemental and compositional analyses of the product oil. Presulfiding of catalyst was carried out in a high pressure continuous apparatus equipped with a fixed bed reactor of $20 \mathrm{ml}$ in volume, using diesel fuel containing $1 \% \mathrm{CS}_{2}$, with varying conditions at $300 \sim 400^{\circ} \mathrm{C}$ under hydrogen pressure of $20 \sim 100 \mathrm{~kg} / \mathrm{cm}^{2} \mathrm{G}$ with LHSV of $1 \mathrm{hr}^{-1}$ and presulfiding time of $0-20 \mathrm{hr}$. Hydrotreating of coal derived middle distillate, obtained from the liquefaction of Wandoan coal using 1 t/day bench unit, was performed successively after presulfiding using same apparatus at $370^{\circ} \mathrm{C}$, under hydrogen pressure of $100 \mathrm{~kg} / \mathrm{cm}^{2} \mathrm{G}$ with LHSV of $1 \mathrm{hr}^{-1}$. Reactant coal liquid, containing 0.33 $\mathrm{wt} \%$ of nitrogen and $1.83 \mathrm{wt} \%$ of oxygen respectively (Table 1), consisted mainly of tetralin, naphthalene, biphenyl, acenaphthene, fluorene, phenanthrene, pyrene, dibenzofuran and carbazole with their alkyl substituted or/and hydrogenated derivatives. According to the analyses of products obtained from the hydrotreating, the weight ratio of tetralin/naphthalene $(\mathrm{T} / \mathrm{N})$, 1,2,3,4,5,6,7,8-octahydrophenanthrene/phenanthrene $(\mathrm{OHP} / \mathrm{PH})$ and dihydropyrene/pyrene decreased and nitrogen content also increased sharply during a short time on stream regardless of catalyst treatment conditions (Figs. 1, 2). This indicates that the activities, both in hydrogenation and in denitrogenation, decrease with time on stream, especially at the early stage of hydrotreating. It takes roughly $30 \sim 40 \mathrm{hrs}$ to stabilize the catalyst activity in our experiments.

Nitrogen content in the products showed lower level at presulfiding temperature of $300^{\circ} \mathrm{C}$ than that at 350 and $400^{\circ} \mathrm{C}$ (Fig. 3). There was, however, no significant difference in $\mathrm{T} / \mathrm{N}$ weight ratio with varying sulfiding temperature (Table 2). Remarkable changes in hydrogenation and in denitrogenation were observed by changing sulfiding time of catalyst (Figs. 4,5,6). Fairly low $\mathrm{T} / \mathrm{N}$ and $\mathrm{OHP} / \mathrm{PH}$ weight ratio of about 2 and 0.2 were observed in the case of sulfiding time of 0 and 5 hrs. These ratio went up to 4 and 0.8 , respectively, and showed almost same value with sulfiding time longer than $15 \mathrm{hrs}$. On the effect of hydrogen pressure, distinguishable change in the composition of the product was not observed (Table 2). Lower nitrogen content in the product, however, was again detected under hydrogen pressure of $40 \mathrm{~kg} / \mathrm{cm}^{2} \mathrm{G}$ for presulfiding compared to that under 20 and $100 \mathrm{~kg} / \mathrm{cm}^{2} \mathrm{G}$ (Fig. 7). Within our experiment, it was concluded that for $\mathrm{Ni}-\mathrm{Mo} / \mathrm{Al}_{2} \mathrm{O}_{3}$ catalyst, optimum presulfiding conditions were $300^{\circ} \mathrm{C}, 40$ $\mathrm{kg} / \mathrm{cm}^{2} \mathrm{G}$ of hydrogen pressure and more than $15 \mathrm{hrs}$ of sulfiding time. Activity of the used catalyst has been examined by the elemental and X-ray diffraction analyses (Fig. 8, Table 5).

\section{Keywords}

Coal liquid, Hydrodenitrogenation, Hydrotreating, Nickel molybdenum catalyst, Sulfiding 